\title{
Hepatic Adenomas Challenges to their Diagnosis and Management with Emphasis on the Bordeaux Classification
}

\author{
Beatrice 1 Madrazo ${ }^{1 *}$, Victor Javier Casillas ${ }^{1}$, Rosa Patricia Castillo ${ }^{1}$, Monica Garcia Buitrago ${ }^{2}$, \\ Emmanuel Thomas ${ }^{3}$, Leonardo Pisani ${ }^{4}$ and Juan Francisco Santoscoy ${ }^{4}$
}

${ }^{1}$ Department of Radiology, University of Miami, Miller School of Medicine, USA

${ }^{2}$ Department of Pathology, University of Miami, Miller School of Medicine, USA

${ }^{3}$ Department of Internal Medicine, University of Miami, Miller School of Medicine, USA

${ }^{4}$ Department of Diagnostic Radiology (2017-2018), University of Miami, Miller School of Medicine, USA

*Corresponding author: Beatrice l Madrazo, Department of Radiology, University of Miami, Miller School of Medicine, USA.

To Cite This Article: Beatrice l Madrazo, Hepatic Adenomas Challenges to their Diagnosis and Management with Emphasis on the Bordeaux Classification. Am J Biomed Sci \& Res. 2019 - 6(4). AJBSR.MS.ID.001052. DOI: 10.34297/AJBSR.2019.06.001052.

Received: 眥 November 19, 2019; Published: 眥 December 03, 2019

\section{Goals and Learning Objectives}

a. To discuss the etiology and natural history of HA.

b. To detail the importance of the Bordeaux Classification.

c. To provide a comprehensive approach to their correct identification based on imaging and pathological features.

d. To present the risk factors associate with hepatic carcinogenesis.

e. To elaborate on the entity of hepatic adenomatosis.

f. To detail on the state-of-the-art management of HA and adenomatosis.

g. To emphasize their association to congenital cardiac conditions and other syndromes.

\section{Disclosure Statement}

Authors have nothing to disclose.

Etiology and Natural History of Hepatic Adenomas (Ha)

It has been postulated that disrupted hepatic vasculature results in the development of hepatic lesions including hepatic adenomas, FNH, and hemangiomas. The etiology of HA is that an altered hepatic circulation stimulates the evolution of hepatic adenomas, FNH and hemangiomas. The stimuli provided by estrogen and anabolic steroids in the genesis of HA is well established and first recognized by Edmundson. They can result from abnormal carbohydrate metabolism such as: in glycogen storage disease, mature onset diabetes mellitus of the young type 3 (MODY3), and metabolic syndrome.

\section{Other factors include}

Anabolic steroids exposure, Fanconi Anemia, glycogen storage disease types I, III and IV, and familial adenomatous polyposis.

\section{RiskFactors Associated with Hepatic Carcinogenesis}

Hepatocellular Carcinoma (HCC) in HA. Risk factors for malignant transformation of HA include: Male sex, glycogen storage disease and Anabolic steroid usage. B-catenin-mutated subtype (highest risk of malignancy) and tumors larger than 5 $\mathrm{cm}$ in maximum dimension. Teaching Point! B-catenin mutated hepatocellular adenomas are interpreted as borderline lesions between hepatocellular adenoma and hepatocellular carcinoma.

Hepatocellular Adenoma: Histology

\begin{tabular}{|c|c|c|c|}
\hline \multicolumn{4}{|c|}{$\begin{array}{c}\text { Bordeaux Classification of HCA } \\
\text { Bioulac-Sage et al. Hepatology 50:481-489. }\end{array}$} \\
\hline 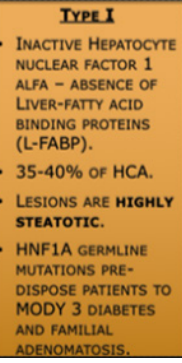 & \begin{tabular}{l}
\multicolumn{1}{c}{ TYPE II } \\
BETA-CATENIN \\
ACTIVATING \\
MUTATIONS. \\
$10-15 \%$ OF HCA. \\
HIGHER RISK OF \\
MALIGNANT \\
TRANSFORMATION. \\
MAY HAVE CENTRAL \\
SCARS.
\end{tabular} & $\begin{array}{l}\text { TYPE III } \\
\text { - INFAMMATORY } \\
\text { CHANGES WITH SERUM } \\
\text { AMYLOID AND C- } \\
\text { REACIIVE PROTEIN } \\
\text { (CRP) EXPRESSION. } \\
\text { - } 50 \% \text { OF HCA. } \\
\text { - INFLAMMATORY } \\
\text { INFLTRATE, } \\
\text { SINUSOIDAL } \\
\text { DILTATION AND } \\
\text { DYSTROPHIC ARTERIES. } \\
\text { - ASSOCIATION } \\
\text { BETWEN OBESIT AND } \\
\text { INFAMMATORY HCA } \\
\text { HAS BEEN IDENTIFIED. }\end{array}$ & $\begin{array}{c}\text { TYPE IV } \\
\text {. UNCLASSIFIED. } \\
<10 \% \text { of HCA. }\end{array}$ \\
\hline
\end{tabular}


HA have dilated sinusoids which are thin-walled capillaries that are perfused by arterial pressure; adenomas lack a portal venous supply and are fed solely by peripheral arterial feeding vessels. Because a tumor capsule is usually absent or incomplete, hemorrhage may spread into the liver or abdominal cavity. Billiary ductules are notably absent from adenomas, a key histologic feature that helps distinguish hepatocellular adenoma from focal nodular hyperplasia [1-7] [Figure 1].

The Bordeaux Classification of Hepatic adenomas represents a multi-center series of 96 liver tumors with a firm or possible diagnosis of HA was reviewed by liver pathologists. This represents a collective experience from 13 French university hospitals encompassing from 1992-2004. All 96 cases were proven HA. Criteria of inclusion in the study had adequate sampling of frozen and fixed liver tissues following hepatectomy (95 cases) or transplantation (1 case). The HA were analyzed and classified according to their genetic profile, pathological and clinical manifestations

\section{HA and Genetic Mutations}

Activation of the B-catenin pathway has been found in HA (18-20) and is present in 20 to $34 \%$ of hepatocellular carcinomas (21-24). Beta Catenin is key in hepatic physiology: cell lineage and differentiation, stem cell renewal, epithelial-mesenchymal transition, proliferation and cell adhesion $(25,26)$. Twentytwo $(4.5 \%)$ patients had HCC transformation. Predictors of HCC transformation, using both univariate and multivariate analyses, were male gender (odds ratio [OR]: 15.0; IC 95\%: $5.4-44.0$ ) and tumor size >10 cm (OR: 6.9; IC 95\%: 2.5 - 20.1).

\section{Bordeaux Classification of HCA}

\section{Type I}

1. Inactive Hepatocyte nuclear factor 1 alfa - absence of Liver-fatty acid binding proteins (L-FABP).

2. $35-40 \%$ of HCA

3. Lesions are highly steatotic.

4. HNF1A germline mutations pre-dispose patients to MODY 3 diabetes and familial adenomatosis.

5. Second most common (30-35\%).

6. Associated with maturity-onset diabetes mellitus of the young (MODY3).

7. Predisposition for hepatic adenomatosis.

8. Develop exclusively in female with history of oral contraceptive use.

9. Intracellular fat results in signal loss on out-of-phase MRI- prevalence $86-100 \%$ Estrogens in OCP act as the genotoxic agent resulting in somatic mutations of the HNF 1 alpha resulting in lipogenesis and hepatocellular proliferation; the resulting silencing of hepatic fatty acid binding proteins in hepatocytes resulting in intracellular fat deposition [Figure 2].

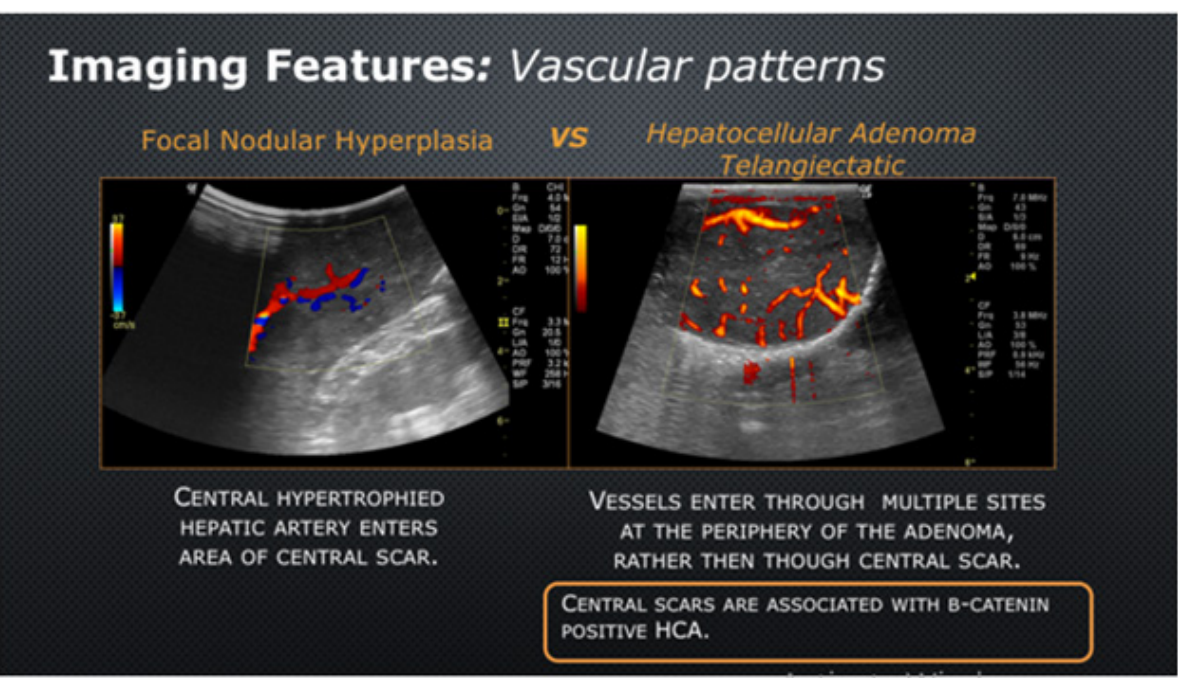

Figure 2:

\section{Type II}

1. Beta-catenin activating mutations

2. $10-15 \%$ of HCA

3. Higher risk of malignant transformation.
4. May have central scars.

5. Prevalence $10-15 \%$.

6. No Specific MRI Patterns.

7. Occur More Frequently in Males, Associated with 
Hormone Administration, Glycogen Storage Disease and Familial Adenomatosis Polyposis Syndrome.

8. B-Catenin is encoded in the beta catenin gene (ctnnb1) located in CHROMOSOME 3Q21.

9. It is the downstream effector of the WNT- $\beta$-catenin pathway which has a major role in liver embryogenesis [Figure 2].

\section{Adenomas - Management}

Surgical due to propensity for bleeding and malignancy.

Lesions > $5 \mathrm{~cm}$; Liver adenomatosis - resection of largest and most vulnerable to hemorrhage (sub-capsular and/or pedunculated), pregnancy and increased risk of hemorrhage [814].

\section{Hepatic Adenomatosis}

a) Etiology is poorly understood; described in 1985 by Flejou et al. familial predisposition. Presence of 10 or more HA's involving both hepatic lobes.

b) Females in their 4-5 decades of life with a $10-24 \%$ prevalence. (6). Associated with non-alcoholic fatty liver disease (NASH).

c) Presence of congenital or acquired hepatic vascular abnormalities.

d) All sub-types of HA may be found in hepatic adenomatosis

e) Elevated serum alkaline phosphatase and gamma glutamyl transferase.

f) Do not respond to withdrawal of steroids.

g) Increased risk for HCC

h) Monitoring with alfa feto-protein.

i) Resection of larger adenomas.

j) Imaging characteristics of adenomas similar to HA not associated to liver adenomatosis

\section{Take Home Points}

I. Imaging characteristics play a key role in determine the surveillance and management of hepatocellular adenomas.

II. Inflammatory hepatocellular adenomas demonstrates peripheral dilated sinusoids (A toll sign), these are not associated with malignant differentiation.
III. Hepatocellular adenomas larger than $5 \mathrm{~cm}$ has greater risk for hemorrhage and rupture.

IV. Malignant transformation of hepatic adenoma is likely low and has a male predominance.

\section{References}

1. Zucman Rossi J, Jeannot E, Nhieu JT, Scoazec JY, Guettier C, et al. (2006) Genotype-phenotype correlation in hepatic adenoma: new classification and relationship with HCC. Hepatology 43(3): 515-524.

2. Grazioli L, Federle MP, Brancatelli G, Ichikawa T, Olivetti L et al. (2001) Hepatic Adenomas: Imaging and Pathologic Findings. Radiographics 21(4): 877-892.

3. Bioulac Sage P, Laumonier H, Couchy G, Le Bail B, Sa Cunha A, et al. (2009) Hepatocellular adenoma management and phenotypic classification: the Bordeaux experience. Hepatology 50(2): 481-489.

4. Bioulac Sage P, Rebouissou S, Sa Cunha A, Jeannot E, Lepreux S, et al (2005) Clinical, morphologic, and molecular features defining so-called telangiectatic focal nodular hyperplasias of the liver. Gastroenterology 128(5): 1211-1218.

5. Welch TJ, Sheedy PF, II Johnson CM, David H Stephens, J William Charboneau, et al. (1985) Radiographic characteristics of benign liver tumors: Focal nodular hyperplasia and hepatic adenoma. RadioGraphics 5(4): 673-682.

6. Barthelmes L, Tait IS (2005) Liver cell adenoma and liver cell adenomatosis. HPB (Oxford) 7(3):186-196.

7. Ribeiro A, Burgart L, Nagorney D, Gregory J Gores (1998) Management of Liver Adenomatosis: results with conservative surgical approach Liver Transplantation and Surgery.

8. Paradis V, Benzekri A, Darge ’re D, Bièche I, Laurendeau I, et al. (2004) Telangiectatic focal nodular hyperplasia: a variant of hepatic adenoma. Gastroenterology 126(5):1323-1329.

9. Romero R (2013) Liver in Congenital heart disease: Implications of the Fontan procedure for pediatric and adult liver specialists. Clinical Liver disease 2(5): 210-214.

10. Paulson EK, McClellan JS, Spritzer CE, Washington K, Meyers WC, et al. (1994) Hepatic adenoma: MR characteristics and Correlation with Pathologic Findings. AJR Am J Roentgenol 163(1): 113-116.

11. Katabathina VS, Menias CO, Shanbhogue AKP, Jagirdar J, Paspulati RM, et al. (2011) Genetics and Imaging o Hepatocellular adenomas: 2011 Update. Radographics 31(6): 1529-1543.

12. Laurent A, Dokmak S, Nault JC, Pruvot FR, Fabre JM, et al. (2016) European experience of 573 liver resections for hepatocellular adenoma: a cross-sectional study by the AFC-HCA-2013 study group. HPB (Oxford) 18(9): 748-755.

13. Daniel Cherqui, Jean Hardwigsen, AFC-HCA-2013 Study Group, Laurent A, Dokmak S, et al. (2016) European experience of 573 liver resections for hepatocellular adenoma: a cross-sectional study by the AFCHCA-2013 study group. HPB (Oxford) 18(9): 748-755.

14. Dhingra S, Fiel MI (2014) Update on the new classification of hepatic adenomas: clinical, molecular, and pathologic characteristics. Arch Pathol Lab Med 138(8): 1090-1097. 